\title{
Double-blind randomised clinical trial of a pepsin- inhibitory pentapeptide (pepstatin) in the treatment of duodenal ulcer
}

\author{
O. BONNEVIE 1 , L. B. SVENDSEN, J. HOLST-CHRISTENSEN, \\ T. STEHR JOHANSEN, J. SøLTOFT, AND P. M. CHRISTIANSEN \\ From the Medical and Surgical Department of Gastroenterology, Hvidovre Hospital, University of \\ Copenhagen, Denmark
}

SUMMARY In a double-blind randomised clinical trial a specific inhibition of peptic activity with a pentapeptide, pepstatin, had no significant advantage over placebo in the ulcer healing and symptomatology of duodenal ulcer. Thus, the inhibition of pepsin in human gastric juice does not appear to have a major influence on the healing of duodenal ulcer.

Secretion of acid and pepsinogen are important in the pathogenesis of the ulcer disease (Schiffrin and Warren, 1942; Alphin et al., 1977). Neutralisation or reduction of acid output has so far formed the basis of most medical and surgical treatments in ulcer diseases. Few data are available on the clinical importance of an elective inhibition of the peptic activity. Most studies have focused on amylopectin sulphate (SN-263), which, however, seems to protect protein against the proteolytic activity of free pepsin rather than to precipitate the pepsin itself (Cammarata et al., 1971; Berstad, 1974; Kim et al., 1975). Amylopectin sulphate seems to accelerate gastric ulcer healing (Zimmon et al., 1969) and to promote a prophylactic effect on the recurrence rate of duodenal ulcer (Sun and Ryan, 1970). However, the drug has been reported to have neither a direct symptomatic effect in patients with radiologically demonstrated duodenal ulcer (Cocking, 1972; Baron, et al., 1977) nor an influence on the ulcer healing rate in patients with an active duodenal ulcer, when evaluated radiologically (Cocking, 1972) and endoscopically (Landecker et al., 1976).

Specific inhibition of the peptic activity by precipitation of pepsin has not been studied in a clinical trial. Umezawa (1970) developed a penta-

\footnotetext{
${ }^{1}$ Address for reprint requests: O. Bonnevie, Medical Department of Gastroenterology, Hvidovre Hospital, University of Copenhagen, DK-2650 Hvidovre, Denmark.

Received for publication 15 December 1978
}

peptide, pepstatin, (isovaleryl-L-valyl-4-amino-3hydroxy - 5 - methylheptanol - L - alamyl - 4-amino - 3hydroxy-6-methylheptanoic acid, molecular weight 686), which binds pepsin in an equimolar pepsinpepstatin complex devoid of proteolytic activity (Kunimoto et al., 1972).

In vitro and in vivo experiments have shown that pepstatin reduces the peptic activity in gastric juice to a greater extent (about $90 \%$ ) (Svendsen et al., 1976) than amylopectin sulphate (about 50\%) (Berstad, 1974). In this study the effect of pepstatin on duodenal ulcer healing and symptomatology was compared with that of placebo.

\section{Methods}

The study comprised consecutive patients with epigastric pains and a duodenal ulcer verified by endoscopy and documented by photography. Ulcers in the duodenal bulb, pyloric canal, and the prepyloric area within $1 \mathrm{~cm}$ from the pylorus were included. Patients with haematemesis or melaena were included only if the bleeding did not require surgery within the first 24 hours after the diagnostic endoscopy.

Patients in whom a stomach operation had been previously performed or in whom a coexisting gastric ulcer was demonstrated were excluded.

The study was carried out as a double-blind randomised clinical trial with registration of the clinical symptoms and morphological findings. 
Pepstatin was given as $100 \mathrm{mg}$ capsules seven times per day on fixed hours. This dosage should, according to the in vivo experiments, be sufficient to inhibit the peptic activity of gastric juice for 18 hours a day (Holm and Berstad, 1976). An identical looking placebo capsule containing $99 \%$ lactose and $1 \%$ magnesium stearate was given in the same dosage. All patients were told to eat normal meals frequently, advised to reduce tobacco, coffee, and alcohol consumption and further instructed to stop intake of aspirin. Patients reporting relief of pains by meals and/or antacids were offered trisilicate tablets neutralising $8.5 \mathrm{mmol}$ acid. Antacids with aluminium hydroxide, which also has a pepsin inhibitory effect (Piper and Fenton, 1964), and anticholinergic drugs were not allowed. Treatment was given for six weeks, unless complete ulcer healing as well as absence of symptoms were observed within that period. Clinical symptoms, acid output, endoscopic and radiological findings were recorded at the beginning of the trial. Repeated endoscopies were performed after two, four, and six weeks of treatment. The endoscopist had no information about actual symptoms or previous findings. The ulcer size was measured by using the open tips of a biopsy forceps $(6 \mathrm{~mm})$ as a reference. At each check symptoms were recorded in a questionnaire. Furthermore the patients kept diaries in which presence of pains, consumption of antacids and test capsules were recorded.

Evaluation of differences between qualitative data were analysed by Fischer's exact test and the $\chi^{2}$ test. Differences between quantitiative data were analysed by the Mann Whitney test. The level of significance was $5 \%$.

\section{Results}

Sixty consecutive ulcer patients admitted to the medical and surgical departments of Hvidovre Hospital as in- or outpatients fulfilled the criteria for entering the trial. During the study only one patient declined to take part, and two patients were not included because of mental incapacity. Four patients were withdrawn from the trial because of symptoms demanding operation: two patients in the pepstatin group before the first check because of bleeding and intolerable pains, and two patients in the placebo group after one and four weeks, respectively, because of pyloric stenosis and suspicion of pancreatic cancer. Another two patients receiving the placebo defaulted from the follow-up at the first and second check, respectively. Thus, a total of 54 patients completed the trial, of whom 28 were treated with pepstatin and 26 with placebo. Data on history and laboratory, radiological, and initial endoscopic findings for the two groups are listed in Table 1. The two groups did not differ significantly by any measurement or in the registration of patient compliances judged on the basis of the diaries. Twenty-six patients $(43 \%)$ were initially admitted to hospital as inpatients, but discharged after an average period of $7 \cdot 1$ days; there was no significant difference between the groups in this respect (Table 1). No patient stayed in hospital during the complete period of treatment. It was noted that all except two patients also had radiological indications of a duodenal ulcer.

\section{ENDOSCOPIC HEALING}

Complete ulcer healing was observed in 14 of 28

Table 1 Comparison of treatment groups

\begin{tabular}{|c|c|c|c|c|c|c|c|c|c|}
\hline \multicolumn{5}{|c|}{ Characteristics } & \multicolumn{3}{|l|}{ Pepstatin (28 patients) } & \multicolumn{2}{|c|}{ Placebo (26 patients) } \\
\hline \multicolumn{5}{|c|}{$\begin{array}{l}\text { Age (yr) } \\
\text { No. of male patients } \\
\text { No. with nocturnal pains } \\
\text { No. with haematemesis/melaena } \\
\text { Median length of history (yr) } \\
\text { No. of cigarette smokers } \\
\text { No. of cigarettes per user per day } \\
\text { No. of drinks per user per day } \\
\text { No. with positive } x \text {-ray findings } \\
\text { Initial ulcer size (mm²) } \\
\text { Average no. of capsules per day } \dagger \\
\text { No. initially admitted to hospital } \\
\text { Average period of hospitalisation (weeks) }\end{array}$} & \multicolumn{3}{|l|}{$\begin{array}{l}58 \cdot 1 \pm 3 \cdot 3(33-80)^{*} \\
21 \\
13 \\
5 \\
4 \\
21 \\
10 \cdot 5 \pm 1 \cdot 9 \\
4 \cdot 2 \pm 1 \cdot 3 \\
28 \\
74 \cdot 9 \pm 18 \cdot 3 \\
6 \cdot 7 \pm 0 \cdot 1 \\
13 \\
5 \cdot 8 \pm 2 \cdot 3\end{array}$} & \multicolumn{2}{|c|}{$\begin{array}{l}62 \cdot 0 \pm 2 \cdot 9(32-85) \\
15 \\
12 \\
5 \\
4 \\
22 \\
9 \cdot 0 \pm 1 \cdot 7 \\
3 \cdot 3 \pm 1 \cdot 3 \\
24 \\
114 \cdot 6 \pm 40 \cdot 3 \\
6 \cdot 7 \pm 0 \cdot 1 \\
13 \\
7 \cdot 2 \pm 2 \cdot 1\end{array}$} \\
\hline & \multicolumn{4}{|c|}{ Pepstatin } & & \multicolumn{4}{|c|}{ Placebo } \\
\hline & Mean & $S I$ & $S E M$ & Range & & Mean & $S I$ & $S E M$ & Range \\
\hline $\begin{array}{l}\text { BAO } \\
\text { PAO }\end{array}$ & $\begin{array}{r}4 \cdot 1 \\
33 \cdot 6\end{array}$ & $\begin{array}{r}6 \cdot 7 \\
16 \cdot 2\end{array}$ & $\begin{array}{l}1 \cdot 2 \\
3 \cdot 1\end{array}$ & $\begin{array}{l}(0.0-34 \\
(10 \cdot 0-6\end{array}$ & & $\begin{array}{r}3 \cdot 8 \\
37 \cdot 0\end{array}$ & $\begin{array}{c}4 \cdot 5 \\
19 \cdot 6\end{array}$ & $\begin{array}{l}0.9 \\
3.8\end{array}$ & $\begin{array}{c}(0 \cdot 0-15 \cdot 2) \\
(8 \cdot 5-88 \cdot 0)\end{array}$ \\
\hline
\end{tabular}

None of the differences between the groups was statistically significant at the $5 \%$ level.

*Mean \pm SEM, with range in parentheses.

†According to patients' diaries. 
Table 2 Endoscopic findings in each group according to initial size of ulcer*

\begin{tabular}{|c|c|c|c|c|c|}
\hline \multicolumn{2}{|l|}{ Ulcer size } & \multicolumn{2}{|l|}{ Pepstatin } & \multicolumn{2}{|l|}{ Placebo } \\
\hline$m m^{2}$ & $d(m m)$ & Ulcer healed & Ulcer not healed & Ulcer healed & Ulcer not healed \\
\hline $\begin{aligned} 0 & <x \leqslant 78.5 \\
78.5 & <\times \leqslant 314 \cdot 0 \\
314 \cdot 0 & <x\end{aligned}$ & $\begin{array}{rl} & d \leqslant 10 \\
10<d \leqslant 20 & d \leqslant d\end{array}$ & $\begin{array}{r}11 \\
3 \\
0\end{array}$ & $\begin{array}{r}11 \\
2 \\
1\end{array}$ & $\begin{array}{r}11 \\
2 \\
2\end{array}$ & $\begin{array}{l}8 \\
3 \\
0\end{array}$ \\
\hline \multicolumn{2}{|c|}{ Total } & $14(50 \%)$ & 14 & $15(58 \%)$ & 11 \\
\hline
\end{tabular}

*Data expressed as number of patients in each group, with percentage of total group in parentheses.

patients $(50 \%)$ in the pepstatin group and in 15 of 26 patients $(58 \%)$ in the placebo group. Thus, healing was not significantly different in the two groups, neither totally nor analysed according to the initial ulcer size (Table 2). Furthermore-in cases with complete healing-there was no significant difference in healing time between the two groups (Table 3). $\mathrm{T}_{\frac{1}{2}}$ (time lapse for $50 \%$ ulcer size reduction) for completely healed ulcers initially having a diameter less than $20 \mathrm{~mm}$ was 1.3 and 1.4 week in the pepstatin and placebo group, respectively.

Table 3 Healing time in completed healed ulcers in each treatment group*

\begin{tabular}{lll}
\hline $\begin{array}{l}\text { Time of complete healing } \\
\text { (weeks) }\end{array}$ & $\begin{array}{l}\text { Pepstatin } \\
\text { (no.) }\end{array}$ & $\begin{array}{l}\text { Placebo } \\
\text { (no.) }\end{array}$ \\
\hline 2 & 4 & 5 \\
4 & 7 & 4 \\
6 & 3 & 6 \\
\hline Total & 14 & 15 \\
\hline
\end{tabular}

*No significant difference between groups.

The complete healing rate was not significantly different in the two treated groups among patients with ulcer in the duodenal bulb (29 cases) and in the pyloric canal/prepyloric area ( 25 cases), respectively. Initial inpatient treatment had no influence on ulcer healing (Table 4).

Fourteen patients treated with pepstatin and 11 patients receiving placebo did not obtain complete ulcer healing. The reduction in size at the end of the trial was not significantly different in the two groups (Table 5).

\section{SYMPTOMATIC RESPONSE}

Complete absence of symptoms occurred in 17 patients $(61 \%)$ receiving pepstatin and in 16 patients $(62 \%)$ receiving placebo, after an average period of 13.2 and 18.5 days of treatment. These differences were not statistically significant. The number of patients without symptoms despite the presence of an ulcer after six weeks of treatment was three in the
Table 4 Complete ulcer healing and period of hospitalisation in patients initially admitted to hopsital

\begin{tabular}{lllll}
\hline \multirow{5}{*}{ Endoscopic finding } & $\begin{array}{l}\text { Pospitalisation (days)* } \\
\text { Patients }\end{array}$ & Pepstatin & $\begin{array}{l}\text { Patients } \\
(\text { no. })\end{array}$ & Placebo \\
\hline Healed & 8 & $3 \cdot 6 \pm 0.7$ & 7 & $7 \cdot 1 \pm 2 \cdot 4$ \\
Not healed & 5 & $9 \cdot 4 \pm 5 \cdot 2$ & 6 & $9 \cdot 5 \pm 4 \cdot 0$ \\
\hline & 13 & & 13 & \\
\hline
\end{tabular}

Neither the differences in rate of ulcer healing nor the period of hospitalisation between the groups was statistically significant at the $5 \%$ level.

*Mean \pm SEM

pepstatin group and two in the placebo group. On the contrary, one and two patients with completely healed ulcer in each group respectively still had epigastric pains at the end of the trial. Among all patients with persistent symptoms after the trial only three treated with pepstatin and one treated with placebo claimed that the symptoms were unchanged or worsened.

The intake of antacids was, on average, 58.9 tablets among 23 consumers in the pepstatin group and 64.9 tablets among 20 consumers in the placebo group; this is not a significant difference. No sideeffects were observed.

\section{Discussion}

In theory, an unfortunate chance variation in ulcer healing in the two groups, the effects of concurrent antacid consumption, or any unequal influence of inpatient treatment could have obscured a true and important healing effect of pepstatin. All seem unlikely. Antacid consumption was modest and equal in the test and control groups, the proportions of inpatients were likewise equal in the two groups, and, finally, examination of the standard error of the treatment difference in the two patient groups (SED: 0.135) suggested that a true effect favouring pepstatin concealed by random variation 
Table 5 Reduction in size of incompletely healed ulcers in each group after six weeks of treatment*

\begin{tabular}{|c|c|c|c|c|c|c|}
\hline \multirow[t]{2}{*}{ Ulcer size } & \multicolumn{3}{|c|}{ Pepstatin } & \multicolumn{3}{|l|}{ Placebo } \\
\hline & Initial & After 6 weeks & Reduction rate $\%$ & Initial & After 6 weeks & Reduction rate \% \\
\hline $\begin{aligned} 0 & <x \leqslant 78.5 \\
78.5 & <x \leqslant 314.0 \\
314.0 & <x\end{aligned}$ & $\begin{array}{l}38 \cdot 2 \\
144 \cdot 9 \\
471 \cdot 0 \dagger\end{array}$ & $\begin{array}{r}33 \cdot 0 \\
107 \cdot 5 \\
125 \cdot 0\end{array}$ & $\begin{array}{l}13.6 \\
25 \cdot 8 \\
73.4\end{array}$ & $\begin{array}{r}51 \cdot 8 \\
145 \cdot 2 \\
-\end{array}$ & $\begin{array}{r}43 \cdot 4 \\
124 \cdot 2 \\
\end{array}$ & $\begin{array}{l}16 \cdot 2 \\
14 \cdot 5 \\
-\end{array}$ \\
\hline
\end{tabular}

*Average ulcer size. No significant difference between treatment groups in different categories of size.

†One patient.

in small numbers should not exceed $18.5 \%$, this would be clinically insignificant.

Apart from these considerations the present study is in agreement with a trial by Landecker et al. (1976), who found no advantage in amylopectin over placebo. In the development of experimental ulcers the presence of peptic activity was shown to be an important factor (Alphin et al., 1977). This experience from in vivo studies in animals fits in with Sun and Ryan's study (1970) showing that duodenal ulcer patients treated prophylactically with amylopectin sulphate had a lower recurrence rate than placebo-treated patients. Thus, the peptic activity of gastric juice appears to be an essential factor in the formation of an ulcer, but seems to have no major effect on either healing or symptoms once the ulcer has been formed.

The lack of effect of pepstatin in our study could be explained by binding of pepstatin to food or loss of pepstatin through the pylorus. Berstad and coworkers (personal communication) found no decrease in pepstatin's peptic binding effect when a surplus of fibrin was added to the medium, and the dose of pepstatin we used was capable of binding over 30 times an average 24 hours pepsin secretion (Svendsen et al., 1976).

However, the methods of examining pepsin and peptic activity are complex, and by small changes in methods different fractions of pepsin are distinguished (Samloff and Dadufalza, 1977). Some fractions may be of greater importance for ulcer formation than others (Taylor, 1961), and some may not be inhibited by the pepstatin we used. Aoyagi et al. (1970) has purified several compounds with pepsin-binding properties, and more laboratory studies are needed before the role of pepsin in ulcer pathogenesis can be substantiated.

Pepstatin and placebo capsules were supplied by H. Lundbeck \& Co. A/S, Copenhagen. The authors are grateful to cand. pharm. H.-E. Høpfner Petersen, Department of Research, H. Lundbeck \& Co. A/S, for his valuable collaboration.

\section{References}

Alphin, R. S., Vokac, V. A., Gregory, R. L., Bolton, P. M., and Tawes, J. W. III, (1977). Role of intragastric pressure, $\mathrm{pH}$, and pepsin in gastric ulceration in the rat. Gastroenterology, 73, 495-500.

Aoyagi, T., Kunimoto, S., Morishima, H., Takeuchi, T., and Umezawa, H. (1971). Effect of pepstatin on acid proteases. Journal of Antibiotics, 24, 687-694.

Baron, J. H., Gribble, R. J. N., Holdstock, D. J., and Misiewicz, J. J. (1977). Double-blind controlled trial of amylopectin sulphate (Depepsen) in the symptomatic treatment of duodenal ulcer. Gut, 18, 723-724.

Berstad, A. (1974). The effect of amylopectin sulphate (SN-263) on the peptic activity of human gastric juice. Acta Hepato-Gastroenterologica, 21, 212-220.

Cammarata, P. S., Bianchi, R. G., and Fago, F. J. (1971). Mechanism of the antipeptic action of amylopectin sulphate (SN-263), an antiulcer, mucin-like agent. Gastroenterology, 61, 850-857.

Cocking, J. B. (1972). A trial of amylopectin sulfate (SN-263) and propantheline bromide in the long term treatment of chronic duodenal ulcer. Gastroenterology, 62, 6-10.

Holm, H. A., and Berstad, A. (1976). Inhibition of gastric peptic activity by antacids and pepstatin. Scandinavian Journal of Gastroenterology, (suppl. 42), 11, 119-121.

Kim, Y. S., Bella, A., Jr., Whitehead, J. S., Isaacs, R., and Remer, L. (1975). Studies on the binding of amylopectin sulphate with gastric mucin. Gastroenterology, 69, 138-145.

Kunimoto, S., Aoyagi, T., Morishima, H., Takeuchi, T., and Umezawa, H. (1972). Mechanism of inhibition of pepsin by pepstatin. Journal of Antibiotics, 25, 251-255.

Landecker, K. D., McCallum, E. M., Fevre, D. I., Green, P. H. R., Kasumi, A., and Piper, D. W. (1976). Effect of sodium amylosulfate (Depepsen) on the healing of duodenal ulcer. Gastroenterology, 71, 723-725.

Piper, D. W., and Fenton, B. H. (1964). Antacid therapy of peptic ulcer. Part II, An evaluation of antacids in vitro. Gut, 5, 585-589.

Samloff, I. M., and Dadufalza, V. (1977). Effect of ionic strength on the proteolytic characteristics of human pepsins (Abstract). Gut, 18, A949.

Schiffrin, M. J., and Warren, A. A. (1942). Some factors concerned in the production of experimental ulceration of the G-I tract in cats. American Journal of Digestive Diseases, 9, 205-209.

Sun, D. C. H., and Ryan, M. L. (1970). A controlled study on the use of propantheline and amylopectin sulphate (SN-263) for recurrences in duodenal ulcer. Gastroenterology, 58, 756-761.

Svendsen, L. B., Guldager, N., Christensen, L., and Christiansen, P. M. (1976). Effect of a pepsin-inhibitory pentapeptide upon the peptic activity and acidity of gastric secretion. Scandinavian Journal of Gastroenterology, 11, 
459-464.

Taylor, W.H.(1961). Gastric proteinases in health and disease. Gastroenterology, 40, 823-826.

Umezawa, H., Aoyagi, T., Morishima, H., Matsuzaki, M., Hamada, M., and Takeuchi, T. (1970). Pepstatin, a new pepsin inhibitor produced by actinomycetes. Journal of Antibiotics, 23, 259-262.

Zimmon, D. S., Miller, G., Cox, G., and Tesler, M. A. (1969). Specific inhibition of gastric pepsin in the treatment of gastric ulcer. Gastroenterology, 56, 19-23.

\section{The June 1979 Issue}

\section{THE JUNE 1979 ISSUE CONTAINS THE FOLLOWING PAPERS}

\section{Sir Arthur Hurst THOMAS HUNT}

Morphology of experimental antibiotic-associated enterocolitis in the hamster: a model for human pseudomembranous colitis and antibiotic-associated diarrhoea A. B. PRICE, H. E. LARSON, AND JULIE CROW

Colonic myoelectrical activity in man: comparison of recording techniques and methods of analysis C. J. STODDARD, H. L. DUTHIE, R. H. SMALlWOOD, AND D. A. LINKENS

Method of preparing isolated colonic epithelial cells (colonocytes) for metabolic studies W. E. W. ROEDIGER AND S. C. TRUELOVE

Cyclic AMP and cyclic GMP levels in human colonic mucosa before and during chenodeoxycholic acid therapy G. R. CORAZZA, R. CICCARELLI, F. CACIAGLI, AND G. GASBARRINI

High flow oxygen therapy for pneumatosis coli S. HOLT, H. M. GILMOUR, T. A. S. BUIST, K. MARWICK, AND R. C. HEADING

Absorption studies in patients six to 10 years after construction of ileostomy reservoirs L. O. NILSSON, H. ANDERSSON, L. HULTÉN, R. JAGENBURG, N. G. KOCK, H. E MYRVOLD, AND B. PHILIPSON

Ultrastructural analysis of plasma cells in coeliac patients M. GUIX, J. M. SKINNER, AND R. WHITEHEAD
Small intestinal intraepithelial lymphocyte levels in cow's milk protein intolerance A. D. PHILlIPS, S. J. RICE, N. E. FRANCE, AND J. A. WALKER-SMITH

Effect of 16,16-dimethyl prostaglandin $E_{2}$ on the gastric mucosal barrier J. P. BOLTON AND M. M. COHEN

Lipid composition of bile in diabetics and obesitymatched controls G. B. HABER AND K. W. HEATON

HLA and cell-mediated immunity in $\mathrm{HB}_{\mathrm{s}} \mathrm{AG}$ negative chronic active hepatitis A. J. M. VOGTEN, R. G. SHORTER, AND G. OPELZ

\section{Clinical trial}

Controlled trial of maintenance cimetidine treatment in healed duodenal ulcer: short and long-term effects M. S. DRONFIELD, A. J. BATCHELOR, w. LARKWORTHY, AND M. J. S. LANGMAN

\section{Case report}

Idiopathic portal hypertension (perisinusoidal fibrosis) after renal transplantation C. NATAF, G. FELDMANN, D. LEBREC, G. DEGOTT, J.-M. DESCAMPS, B. RUEFF, AND J.-P. BENHAMOU

\section{Progress report}

Antacids and peptic ulcer-a reappraisal T. MORRIS AND J. RHODES

Notes and activities; Books

Copies are still available and may be obtained from the PUBLISHING MANAGER, BRITISH MEDICAL ASSOCIATION, TAVISTOCK SQUARE, LONDON WC1H 9JR, price $£ 3.50$, including postage 